\title{
Высокопроизводительная запись ТЛИППС на тонких плёнках Нf астигматическим гауссовым пучком фемтосекундного лазера
}

\author{
Д.А. Белоусов", А.В. Достовалов, В.П. Корольков, \\ С.Л. Микерин, К.А. Бронников, С.А. Бабин \\ Институт автоматики и электрометрии СО РАН \\ "E-mail: $\underline{\text { d.a.belousov91@gmail.com }}$
}

DOI: 10.31868/RFL2020.150-151

Формирование термохимических лазерно-индуцированных периодических поверхностных структур (ТЛИППС) осуществляется в результате воздействия слабосфокусированного импульсного лазерного излучения на поверхность модифицируемой металлической плёнки. ТЛИППС представляют собой параллельные оксидные дорожки, выступающие над поверхностью исходного уровня металла. Сканирование слабосфокусированным лазерным пучком позволяет модифицировать большую площадь обрабатываемого материала, получая на его поверхности непрерывную периодическую структуру. В предыдущих исследованиях было показано, что использование астигматически сфокусированного гауссова пучка, который имеет эллиптическую форму фокального пятна с соотношением сторон 1:10 и размером вдоль большой оси $\approx 150$ мкм, позволяет увеличить усреднённую ширину следа (УШС) модифицированной лазерным излучением области при однопроходном сканировании, по сравнению с использованием записывающего лазерного пучка круглой формы [1]. При этом УШС, характеризующая производительность записи, также зависит и от параметров записи, таких как мощность записывающего пучка (P), скорость сканирования (V) и величины перекрытия соседних следов. Вместе с тем, параметры записи влияют на дефектность, период и упорядоченность сформированных оксидных дорожек. Характеристики сформированных ТЛИППС также зависят и от многих других факторов, например, от параметров модифицируемого материала. В связи с этим, в настоящее время проводятся исследования направленные, в том числе, на поиск материалов наиболее пригодных для данной технологии модификации поверхности. В данной работе проведено исследование параметров структур ТЛИППС, сформированных на тонких пленках Нf толщиной 15 нм.

Запись исследуемых структур производилась на установке прецизионной фемтосекундной модификации материалов [2]. Скорость сканирования в экспериментах составляла 100-500 мкм/с для мощности записывающего пучка 200 мВт, 100-2000 мкм/с для мощности 250 мВт и 300-2000 мкм/с для мощностей 275 и 300 мВт. Исследование параметров ТЛИППС осуществлялось по анализу их микроизображений (рис. 1а-б), с использованием алгоритма, описанного в работе [3]. Полученные результаты показывают, что при увеличении скорости сканирования до 2000 мкм/с УШС записанных ТЛИППС уменьшается незначительно (рис. 1в) но при этом существенно уменьшается относительная площадь дефектов (ОПД) сформированных структур (рис. 1г). Это вызвано уменьшением дозы экспозиции полученной материалом в центральной области записывающего пучка. Таким образом, полученные результаты показывают, что Hf является потенциально перспективным материалом, для высокопроизводительного формирования ТЛИППС. 

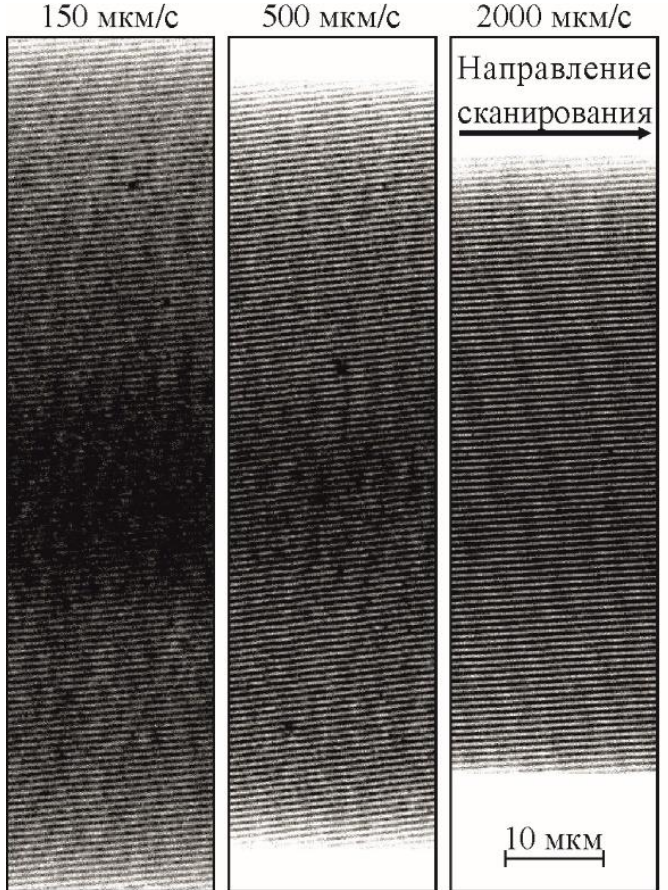

a)

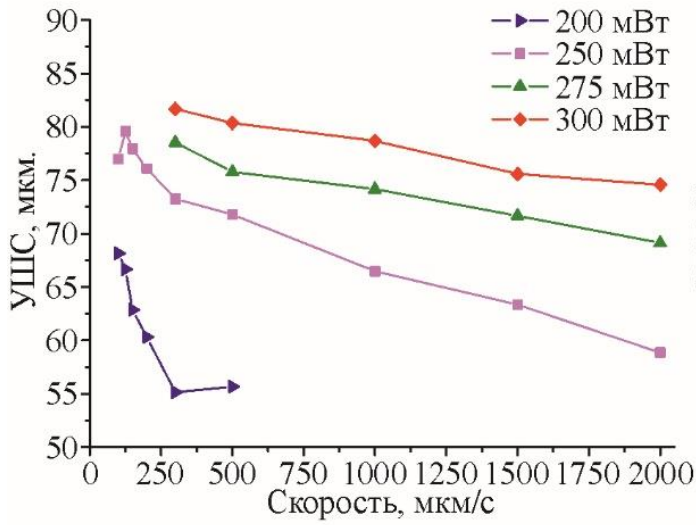

B)
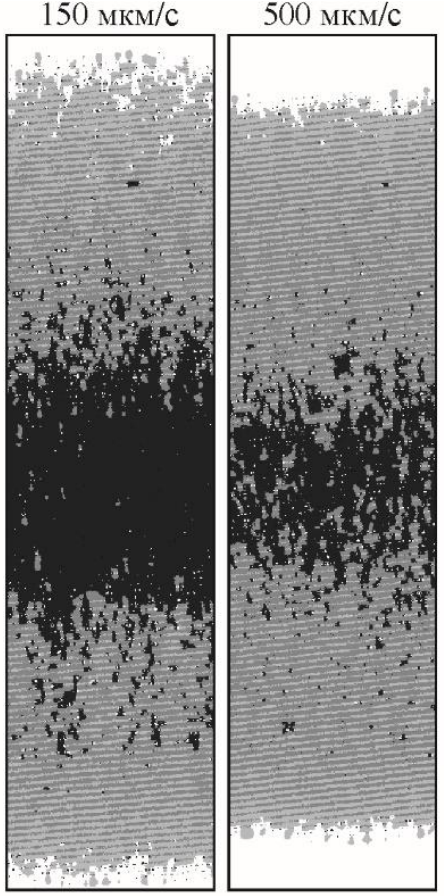

ธ)

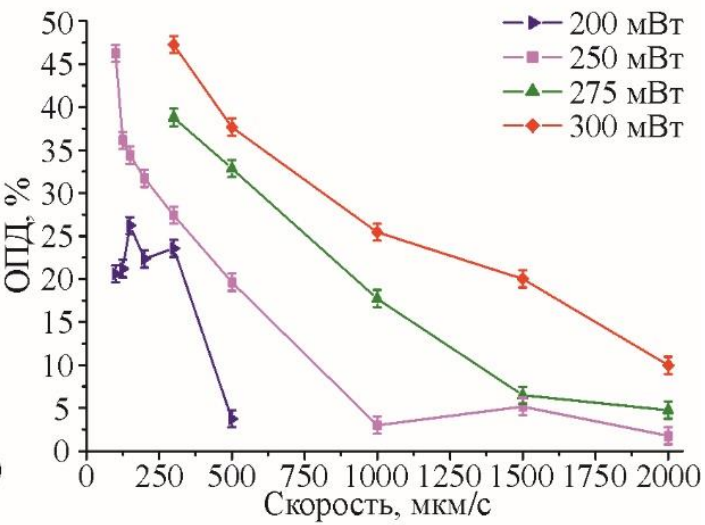

г)

Рис. 1. Анализ микроизображений ТЛИППС: а) фрагменты обрабатываемых микроизображений $(\mathrm{P}=250 \mathrm{MBT})$; б) фрагменты микроизображений после выделения дефектных областей ТЛИППС (чёрные пиксели) и областей не обработанных лазерным излучением (белые пиксели); в) усреднённая ширина следа ТЛИППС; г) относительная площадь дефектов ТЛИППС.

Работа выполнена с использованием оборудования ЦКП «Спектроскопия и оптика» ИАиЭ СО РАН, за счет средств субсидии на финансовое обеспечение выполнения государственного задания (№ гос. регистрации АААА-А17-117052210002-7) в части обработки микроизображений и за счёт средств гранта РФФИ №19-32-90235 в части формирования ТЛИППС.

\section{Литература}

[1] А.В. Достовалов, В.С. Тереньтьев и др., Прикладная фотоника 5, 157-172 (2018)

[2] A.V. Dostovalov, K.A. Okotrub et al, Laser Physics Letters 16, 026003 (2019)

[3] Д.А. Белоусов, А.В. Достовалов и др., Компьютерная оптика 43, 936-945 (2019) 